\title{
Elmer Clark Stevenson
}

Elmer Clark Stevenson died 26Feb. 2005, with his family at his side, after a brave battle against leukemia. He was 89. Born 20 Aug. 1915 in Pine City, Wash., to Frederick and Lottie Stevenson, he moved with his family to Pullman, Wash., at the age of 5 and to St. Paul, Minn., at the age of 10 . When he was 15 , the family moved to Washington, D.C. Steve, as he was known to family and friends, graduated in 1933 from Central High School in Washington, D.C. He attended the University of Maryland in College Park from 1933 to 1937, graduating with a BS in agriculture with a major in botany science.

In Fall 1938, he moved to Madison, Wis., to attend the University of Wisconsin. In September 1939, he married his high school sweetheart, Margaret Hammers, in Washington, D.C. The couple lived in Madison until 1942 when he received his $\mathrm{PhD}$ with a joint major in plant pathology and agronomy and a minor in plant physiology. He was employed by the Agronomy Department at the University of Wisconsin during Summer and Fall 1942 before accepting a position with the U.S. Department of Agriculture (USDA) in Beltsville, Md. He worked for the USDA as a plant pathologist in the Division of Drug and Related Crops.

In May 1948, he accepted a position as associate professor of horticulture at Purdue University in West Lafayette, Ind. He was promoted to professor in 1953 and was appointed head of the Horticulture Department in 1958. During his tenure at Purdue, his accomplishments included publication of research on mint production and mint diseases; research on the implementation of mechanical harvesters in the production of tomatoes; and the production of seedless watermelon. As head of Purdue's Horticulture Department, he was instrumental in establishing a horticulture park on campus that is still a favorite among students and faculty at the university. Also as department head, he established a landscape architecture major that grew in such stature that the department was later renamed the Department of Horticulture and Landscape Architecture.

In 1967, he moved his family to Corvallis, Ore., to work for Oregon State University as the associate dean and head of resident instruction at the School of Agriculture (now College of Agriculture). During his tenure at Oregon State, he oversaw a major revision of the university's agricultural curriculum. He retired in 1980. In 1991, he was inducted into Oregon State University's Diamond Pioneer Registry that honors its members' contributions to the development of Oregon agriculture and natural resources and support of OSU programs.

Music played an important part in his life. He enjoyed singing in high school, college, and church choirs. He was a member of a barbershop quartet with other faculty at Purdue University. While living in Corvallis, he directed the First Congregational Church choir for nine years, and "retired" from singing after being a member of the First Presbyterian Church choir.

Throughout his life, he enjoyed gardening. While in Indiana, the family had a small farm and sold fruit and vegetables locally. In Oregon, he enjoyed spending time in his greenhouse and gardens raising tomatoes, corn, seedless watermelon, winter squash, and other fruit and vegetables for family and friends. After retiring, he was active in the Good Samaritan Hospital Auxiliary for 15 years, serving as a volunteer at the hospital and as an officer of the organization. He was appointed the auxiliary's first male president.

He is survived by four sisters; his wife Margaret; children Carol Poe of Franklin, Ind., Dr. Craig Stevenson of Portland, Ore., James Stevenson of Arcadia, Calif., Karen Hedrick of Davis, Calif., Heather Jones of Corvallis, Ore., and Richard Stevenson of Corvallis, Ore.; and 16 grandchildren. He was preceded in death by a brother and two sisters. 